\title{
Importance of Home Gardens in Rural Zone of the Municipality of Abomey-Calavi in South of Republic of Benin
}

\author{
Adjahossou Baï Sêdami ${ }^{1}$, Adjahossou Vidédji Naéssé ${ }^{2}$, Gbénou Pascal $^{3}$ \& Adjahossou Dossou Firmin ${ }^{4}$ \\ ${ }^{1}$ Department of the Environment's Engineering, University of Abomey-Calavi (Benin), Laboratory of Research \\ in Applied Biology (LARBA), Polytechnic School of Abomey-Calavi, Benin \\ ${ }^{2}$ Faculty of Science and Technique, Polytechnique, National University of Sciences, Technologies, Engineering \\ and Mathmatics (UNSTIM), Laboratory Pierre PAGNEY, Water, Ecosystems and Development (LACEEDE), \\ Benin \\ ${ }^{3}$ University of Agriculture of Ketou (UAK), Adjohoun, Benin, West Africa, Laboratory for animal Ecology and \\ Zoogeography Researh (LaREZ), Ketou \\ ${ }^{4}$ Faculty of Agricultural Sciences, University of Abomey-Calavi, Benin \\ Correspondence: Adjahossou Baï Sêdami, Department of the Environment's Engineering, University of \\ Abomey-Calavi (Benin), Laboratory of Research in Applied Biology (LARBA), Polytechnic School of \\ Abomey-Calavi, Benin. E-mail: sedajas@yahoo.fr
}

Received: August3, 2017 Accepted: September 13, 2017 Online Published: October 29, 2017

doi:10.5539/sar.v6n4p150 URL: https://doi.org/10.5539/sar.v6n4p150

\begin{abstract}
In the municipality of Abomey-Calavi in the Department of the Atlantic in South Benin, home gardens constitute at least $35 \%$ of the families' monthly sources of food, fruit, poultry and pigs. 43 home gardens were visited and 30 were selected by reasoned choice for the survey itself. The objective of this study is to show the contribution of these home gardens to the food security of rural populations. The data concerned the size, floristic composition, phytogeographical distribution, the years of creation of home gardens, the various uses of plants, the incomes brought by plants such as bananas, palm trees, coconut trees and teak. Individual structured interviews were used to interview households. Indices of diversity such as Shannon-Wiener and Jaccard have made it possible to categorize these home gardens and to specify their biological richness. The size of these gardens ranges from $200 \mathrm{~m}^{2}$ to $8300 \mathrm{~m}^{2}$. The average percentage of species grown in home garden is $55 \%$ for their nutritional values, $29 \%$ for their medicinal values, $7 \%$ for the wood and energy needs of the populations. Half of the species found, have a wide geographical distribution. Income from these agrosystems sometimes cover partially or totally the children's school fees. This study has therefore shown the importance of home gardens in the municipality of Abomey-Calavi in a context of climate variability and increasingly pronounced demographic pressure on natural resources.
\end{abstract}

Keywords: home garden- in rural zone-phytodiversity-agrosystems-income, South of Republic Benin

\section{Introduction}

As in all countries in southern Sahara, Benin's agriculture faces several problems (low productivity, climate variability, financial difficulties, contingencies ...). Benin is often considered as an agricultural country, Benin has no convincing conceptual basis and no adequate human, technical and financial resources to benefit from optimum productivity. At the same time, traditional practices, potential sources of efficient innovations, are increasingly ignored. This is the case of the home gardens in the rural areas of the Abomey - Calavi commune of the Atlantic Department. Indeed, in this commune, food and nutrition remain very precarious especially for the rural populations. Food supply is ensured through family production around the huts, which through rational use of arable land provides roughly the minimum energy requirements for the populations (Cresta et al., 1994). Previous research, incorporating the study of the agrarian landscape of the Atlantic Department (Adjahossou, 2005), indicates a persistence of dispersed habitat, characterized by home gardens. These gardens blend harmoniously into the agrarian landscape of this department and many authors have demonstrated its performance by showing that the concept of 'home garden' is a holistic approach that ensures a permanent link between grassroots development and Conservation of agrobiodiversity (Okigbo, 1990, Castineiras et al., 2001, 
Abede, 2005). In terms of conservation of plant resources, in situ conservation is more effective (Allomasso, 2001, Castineiras et al., 2001). Multi-crop agrosystems are energy efficient and provide the best food security (Steiner, 1985; Mapongmetsem et al., 2002; Adjahossou, 2005). Home gardens are practiced in several regions of the world (Das and Das, 2005; Nair, 2006; Pulido et al., 2008; Aworinde and Erinoso, 2013). In the tropical zone, they constitute low-input agrosystems, produce continually, foodstuffs like cassava, taro, various fruits and vegetables. Even though production remains low, it nevertheless covers a significant proportion of domestic needs (Maroyi, 2009). The needs of households can be satisfied in terms of food, nutrition, medicinal, energy, ritual, ornamental ... while conserving plant biodiversity (Adjahossou et al., 2016). Home gardens are therefore both an effective means of conserving agro-biodiversity and a diversified production system. Thus, faced with the rapid deterioration of the environment, they contribute to the preservation of old neglected cultivars in a modern agriculture based on productivism and guided by the law of the market. In addition, the multi-plant provisions of the various plant species inhibit environmental degradation due to monocultures (Nair, 1993). These gardens also offer economic advantages (Zaman et al, 2010; Tynsong and Tiwari, 2010; Neelamegam et al., 2016) and sociability while remaining environmentally sustainable. More and more researchers have begun to focus on these particular agrosystems. This reflects a certain awareness of the importance of the home gardens and their role in the future. However, many aspects of agronomy and socio-economics remain to be studied in order to improve their productivity (Mercer and Miller, 1998; Mohan, 2004).

This study aims to better understand concerning the structural bases and modes of operation of these agro-systems to set benchmarks for agricultural modernization integrating the main concerns of farmers that include optimizing agricultural yields.

\section{Study Area}

The municipality of Abomey-Calavi is located in the department of "Atlantique" in the South of the Republic of Benin and is the largest commune of the Department. It is limited to the "Océan atlantique " in east by the municipalities of Sô-Ava and Cotonou, in west by the municipalities of Tori-Bossito and Ouidah in the north by the municipality of Zè. This municipality has a little hilly relief with a sandy strip, spits, a plateau of "Terre de barre" soil and some depressions. Most of the territory of the municipality of Abomey-Calavi is occupied by tropical ferruginous soils and sandy soils. The climate is of the subequatorial type marked by two rainy seasons and two dry seasons. The rainfall of the locality is $1200 \mathrm{~mm}$. Maximum temperatures are always below $35^{\circ} \mathrm{C}$. Minimum temperatures between 20 and $23^{\circ} \mathrm{C}$ are recorded from July to September. The average monthly temperatures vary between 27 and $31^{\circ} \mathrm{C}$ and the annual amplitudes vary between 3 and $4^{\circ} \mathrm{C}$.

\section{Data Collection}

During the exploratory survey in the commune of Abomey especially in areas such as Kpotomey, Wawata-Fanmin, Wawata-Fandji, Wawata-Dangbodji, Glégbo Yêvié-KondonminYêvié, Djindjinkanmin.43 home gardens having at least two plants were visited and 30 were selected by reasoned choice for the survey itself. Data collection was carried out using the participatory research method through unstructured interviews, semi-structured group interviews and individual structured interviews. The main parameters studied are: the structure and floristic composition of home gardens, the usefulness of species, the area occupied by the species, the classification of home gardens by the number of species found. The data collected were coded and subjected to different treatments such as descriptive statistics correlation tests and hierarchical classification. This classification made it possible to group the different species in relation to significant parameters. To compare the home gardens, Jaccard's diversity index of Shannon and dissimilarity were calculated to appreciate the specific diversity to the study area. Thus, in order to understand the relations between the different gardens, Jaccard's similarity index (IJ) is calculated by the formula:

$$
I_{J}=100 \times \frac{c}{a+b-c}
$$

Where $\mathrm{a}$ and $\mathrm{b}$ denote respectively the number of species of the areas $\mathrm{A}, \mathrm{B}$ and $\mathrm{C}$ the numberof species common to both environments.

Similarly, the Shannon H index has specified the structure of populations.

$$
\mathrm{H}=-\sum_{\mathrm{i}=1}(\mathrm{Ni} / \mathrm{N}) \log 2(\mathrm{NNi} / \mathrm{N})
$$

$\mathrm{Ni}=$ number of individuals of species (i)

$\mathrm{N}=$ total number of individuals in the $\mathrm{Ni} / \mathrm{N}$ group = relative frequency of individuals of the species (i) 
The estimated income from the gardens was made taking into account what the promoters of the home gardens said and making some overlaps in the local markets such as the market of Zinvié and Glo-Djigbé. But in addition, we try to verify indirectly by interviewing other members of the same households.

\section{Results}

\subsection{Description of Home gardens}

The majority of the respondents, $90 \%$ of whom are men, are Aïzo (90\%) followed by Toffinous (7\%) and 3\% fons. On average, the home gardens explored have between 5 and 40 years of existence. Figure 1 shows the distribution polygon of the home garden areas.

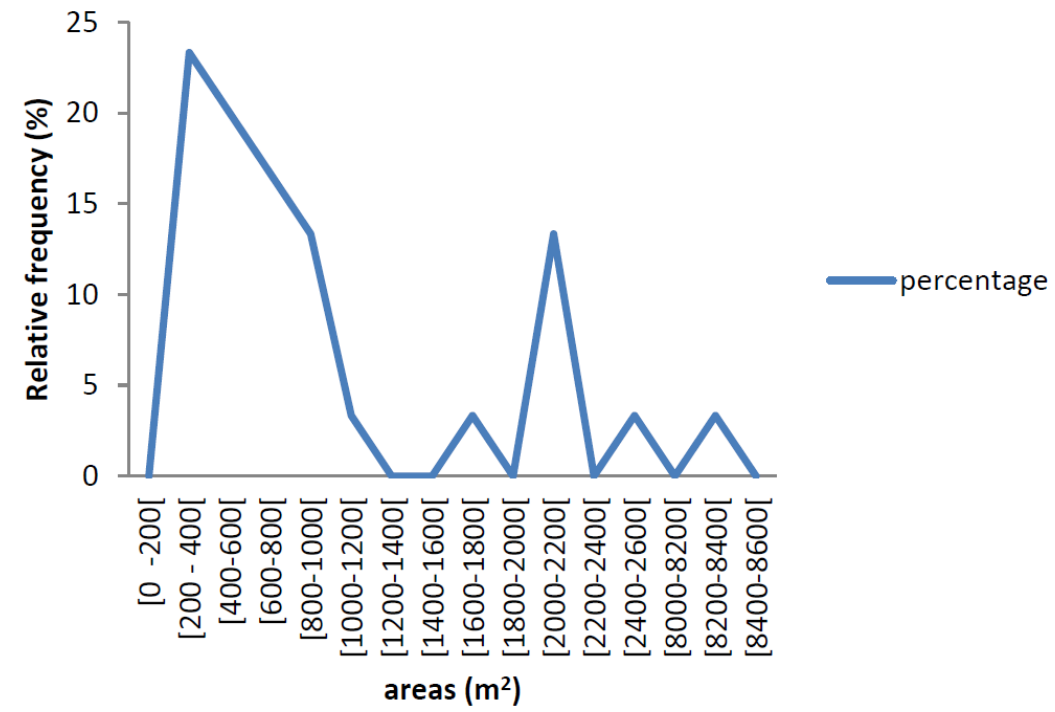

Figure 1. Distribution polygon of the home garden areas

The size of these farms varies from $200 \mathrm{~m}^{2}$ to $8300 \mathrm{~m}^{2}$ with an average of $1053 \mathrm{~m}^{2}$. For $77 \%$ of the home gardens, the areas are between $200 \mathrm{~m}^{2}$ and $1200 \mathrm{~m}^{2}$. The mode of this set is located between $200 \mathrm{~m}^{2}$ and $400 \mathrm{~m}^{2}$. The remainder of the sample is less homogeneous and contains the highest areas, ranging from 1400 to $1830 \mathrm{~m}^{2}$. 103 species were recorded in the 30 home gardens and belong to 87 genera and 56 families. On average, there are 13 species per home garden. The most widely represented families are Euphorbiaceae (14\%), Asteraceae (11\%), Caesalpiniaceae (11\%), Rutaceae, Poaceae (7\%), Mimosaceae (7\%) and Moraceae (7\%). etc.

Figure 2 shows a highly significant positive correlation between the number of cultivated species and the size of the home garden studied. The approximation of the size of the home garden and that of the corresponding households also shows a positive and highly significant correlation between the two factors (Figure 3).

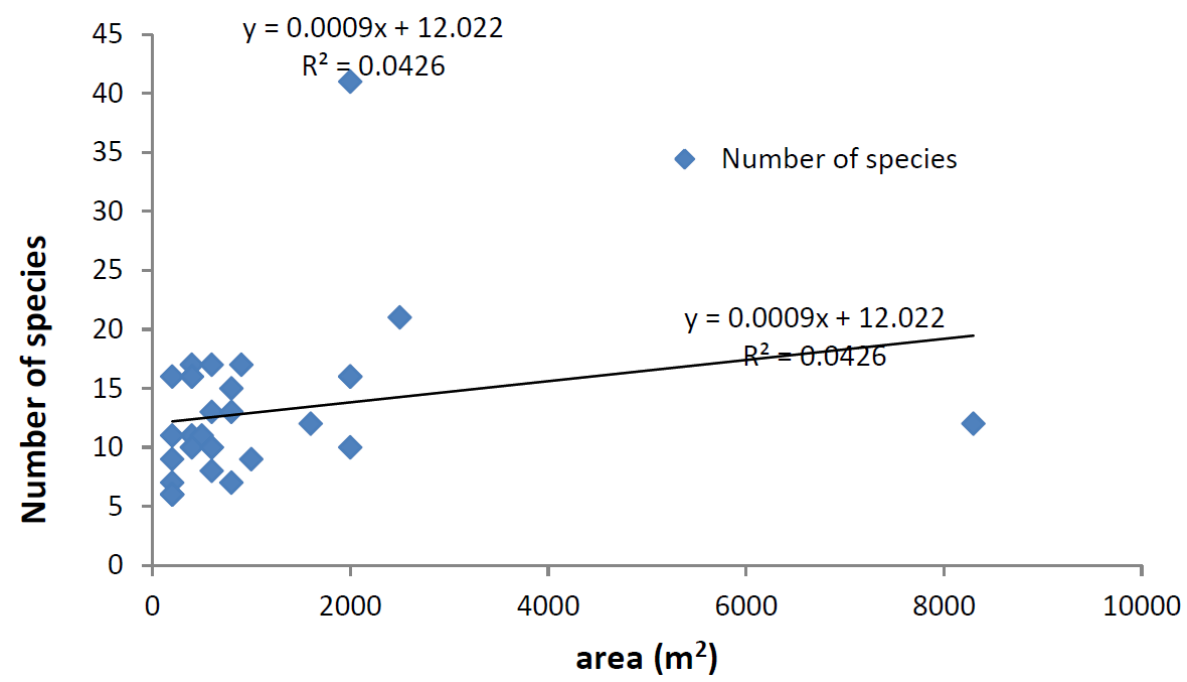

Figure 2. Number of species according to the area of homegarden 


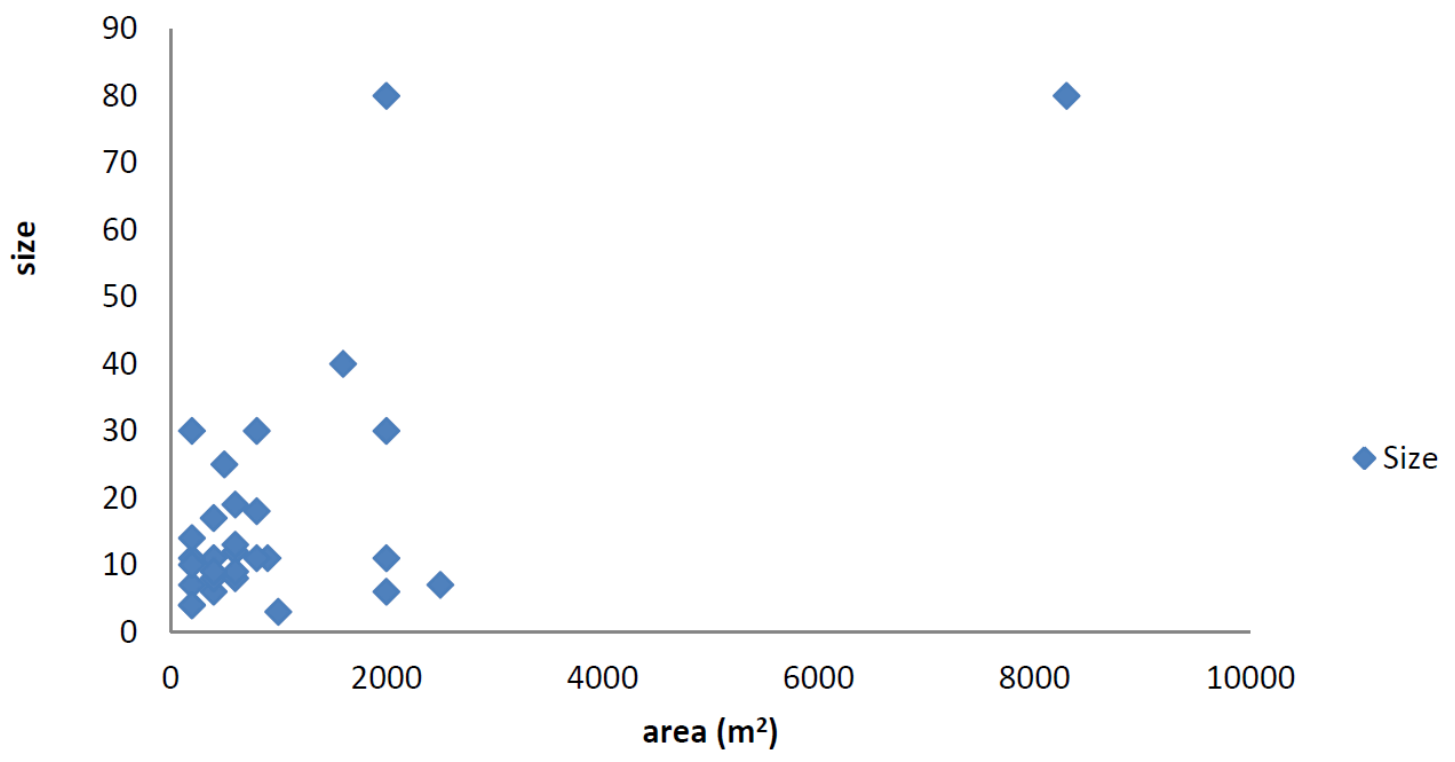

Figure 3. Relationship between size of household and area of home garden

The majority of households have a size between classes [10 - 20 [with 12 as a mode. On the other hand, for two large areas of $2000 \mathrm{~m}^{2}$ and $8300 \mathrm{~m}^{2}$. Those who promote them are members of the same community who number 80 individuals at each area and where the dominant species are fruit trees like coconut.

Figure 4 shows proportions of the home gardens in which the different organs are used. Thus, fruit trees are found in 56\% of the home gardens. Fruits of 33 different species are used in the explorated home gardens. Per household, on average seven species are fruit trees. The most common species are: Musa sinensis (93.57\%), Coco nucifera (80\%), Carica papaya (66. 66\%), Citrus sinensis (40\%), Mangifera indica (36.66\%), Citrus aurantifolia (33. 33\%), Persea americana (23. 33\%), Psidium guajava (23. 33\%), Ananas communis (20\%), Chrysophyllum albidum (20\%).

In $36 \%$ of the home gardens visited, the leaves of 60 species as Newbouldia laevis (36.66\%); Cassia siamea (33.33\%), Vernonia amydalyna (33.33\%), Moringa oleifera (23.33\%), Musa sinensis (16.66\%), Cymbopogon citratus, Annona muricata, Acacia auriculiformis, Carica papaya (13.33\%) and others as Elaeis guineensis, Bombax brevicuspe, Ocimum gratissimum, Passiflora edulis, Eucalyptus camadulensis, Cocos nucifera, Persea americana, Caesalpinia bonduc, Garcinia kola, Irvingia gabonensis, Tectona grandis, Vertivera zizanoides etc. are used.The roots and bark are used in 5\% and 3\% of the home gardens respectively. The bark species as Cassia siamea, Azadirachta indica, Newbouldia laevis, Cocos nucifera, Blighia sapida, Chrysophyllum albidum, Pterocarpus santalinoides, Rauvolfia vomotoria are used in nine home gardens.There are six households that use the roots of 14 species such as Newbouldia laevis, Citrus aurantifolia, Eucalyptus camadulensis, Cocos nucifera, Cyperus esculentus, Acacia auriculiformis, Caesalpinia bonduc, Colocassia esculenta, Cyperus esculentus, Delonix regia, Discorea sp., Manihot esculenta, Ocimum gratissimum, Paullinia pinnata, Petiveria alliacea.

\subsection{Importance of Home Gardens}

Figure 5 shows the importance of the plants recorded in the home gardens. Plants are used for nutritional, medicinal, ornamental, ritual, timber, shade, utensil and dye purposes. Food plants are dominant 55\% versus 29\% for medicinal plants. $7 \%$ are used as timber $(7 \%), 3 \%$ as ritual plants $(3 \%)$, the plants serve as shelter for the household $(3.69 \%)$ or the manufacture of utensils $(1 \%)$. 


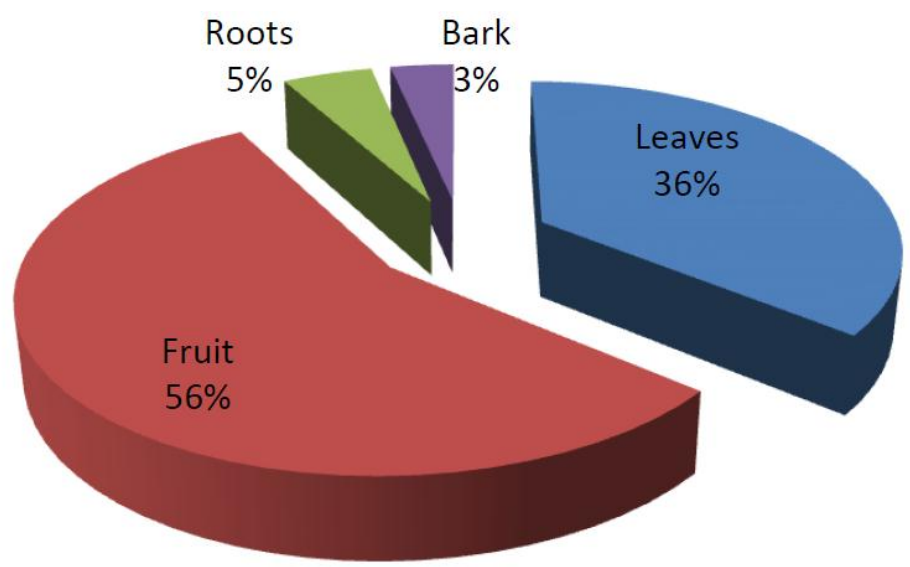

Figure 4. Proportion of home garden in which organs are used

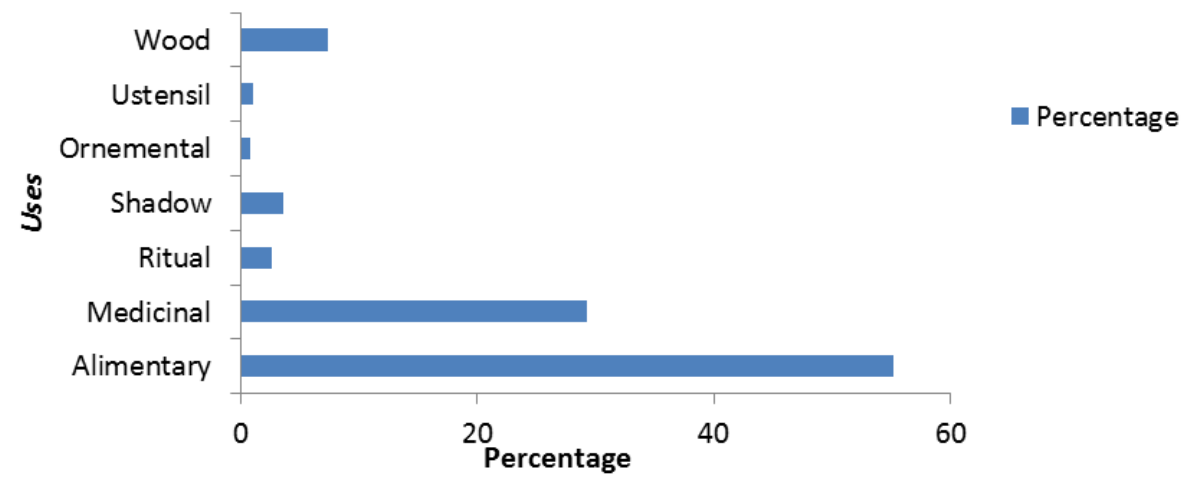

Figure 5. Relative importance of plants listed in the home gardens

The main food crops listed are: Musa sinensis (80\%), Carica papaya (63\%), Elaeis guineensis (60\%), Mangifera indica (37\%), Vernonia amygdalina, Psidium guajava (30\%), Citrus sinensis (30\%), Persea americana (23\%), Annona muricata (23\%), Ananas comosus (17\%), Chrysophyllum albidum (17\%), Moringa oleifera (17\%). An average of seven species are used to feed the household 59 species are used as medicinal plants, the main ones: Newbouldia laevis (33\%), Cassia siamea (30\%), Citrus aurantifolia (30\%), Acacia auriculiformis (13\%), Azadirachta indica (13\%), Bombax brevicuspe (13\%), Caesalpinia bonduc (10\%), Cocos nucifera (10\%), Mangifera indica (10\%), Moringa oleifera (10\%). In addition to other species such Blighia sapida, Carica papaya, Chrysophyllum albidum, Citrus limon, Citrus aurantium, Delonix regia, Eucalyptus camadulensis, Irvingia gabonensis, Ocimum gratissimum, Persea americana etc... are used to a lesser extent. On average, 4 medicinal species are used per household in 25 home gardens. A dozen species such as Newbouldia laevis, Cissampelos owariensis, Croton zambesicus, Acacia polyacantha, Ocimum basilicum, Ocimum canum, Rauwolfia vomitoria, Triplochiton scleroxylon etc... are found in six home gardens for ritual purposes.

Twenty households use cash as Newbouldia laevis, Jatropha curcas, Moringa oleifera, Rauwolfia vomitoria, Campechium, Cassia siamea, Eucalyptus camadulensis Acacia auriculiformis, Bambusa vulgaris, Delonix regia, Tectona grandis as firewood. In the middle of the houses, trees serve as shelters for households especially during the dry season. This is among other Azadirachta indica, Newbouldia laevis, Cola nitida, Ficus capensis, Ficus umbellata, Garcinia kola, Irvingiagabonensis, Lecaniodiscus capanioides, Passiflora edulis, Terminalia catappa etc. In four households Crescentia cujete is used to make cooking utensils such as water calabashes or to collect alcoholic beverages made from the sap of the oil palm. It is noteworthy that in the home gardens explored, ornamental plants are almost non-existent. Nevertheless, Nerium oleander was found in a home garden. The home gardens are relatively diversified, it is necessary to study their floristic composition. 


\subsection{Plant Composition and Phytogeographical Distribution of Home Gardens}

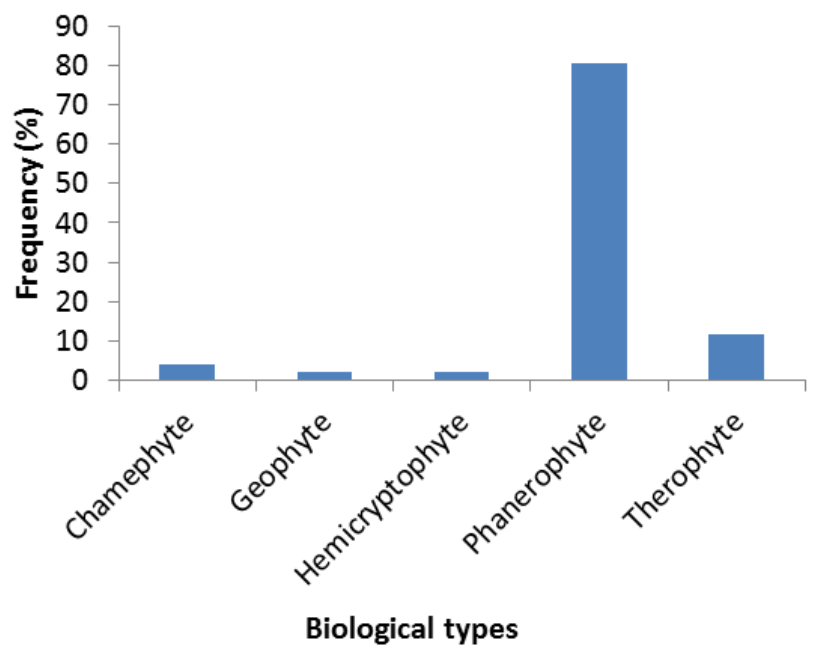

Percentage

Figure 6. Biological spectrum of home gardens

Figure 6 represents the floristic composition of the home gardens recorded in the study area. Almost $80 \%$ of the species are phanerophytes followed by therophytes $(12 \%)$. On the other hand, the chamephytes, the geophytes and the hemicryptophytes represent only $4 \%$ respectively; $2 \% ; 2 \%$ (Figure 6). Nevertheless, almost all biological types are found.

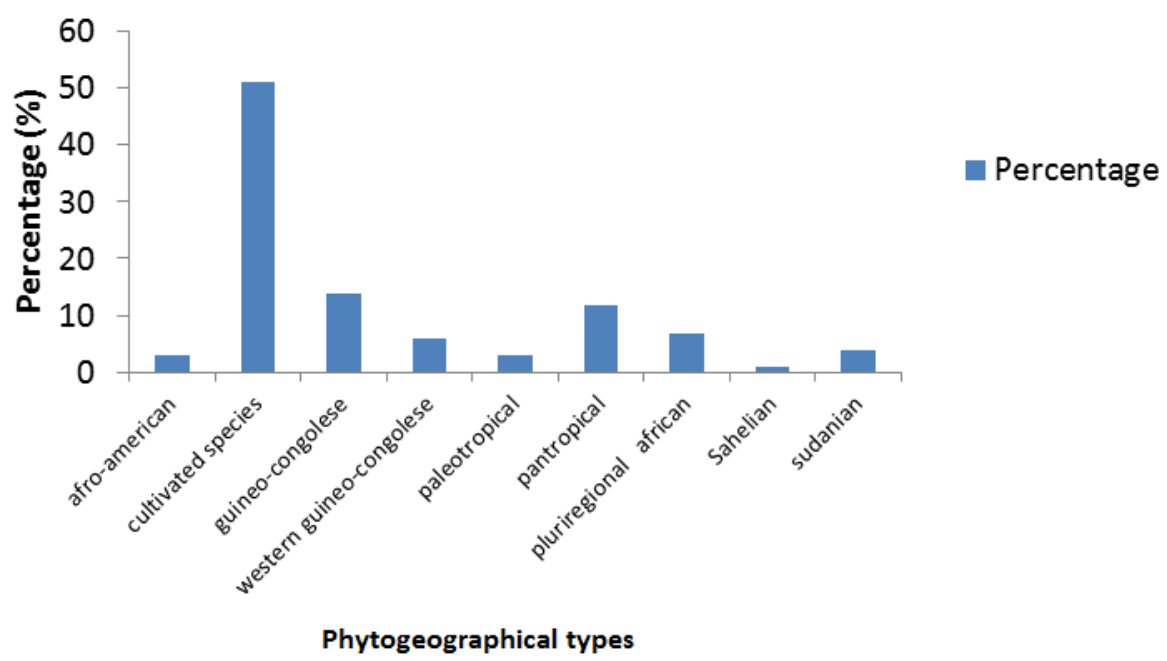

Figure 7. Phytogeographical distribution of home gardens in rural zone

As for figure 7 above, it indicates the phytogeographical distribution of agrosystems. There is dominance of species with a wide geographical distribution $(51 \%)$ followed by a small proportion of Guineo-Congolese base species (14\%) and Western Guineo-Congolese species representing 6\%.

\subsection{Multivariate Analysis of Home Gardens}

The ascending hierarchical classification "agglomerative cluster analysis" has grouped the home gardens according to their floristic composition. Based on the Ward algorithm, the home gardens were classified into four categories according to their similarity for $\mathrm{R} 2=60 \%$. A first category consists of 14 home gardens of 6 to 16 species with an area. This group can be subdivided into two lots, one of which comprises 6 home gardens with about 9 species and an average area of $400 \mathrm{~m}^{2}$ and the other group comprises 8 gardens with 11 species on average with an area of $737 \mathrm{~m}^{2}$. The second category comprises 6 home gardens with an average area of $1083 \mathrm{~m}^{2}$ with an average of 12 species. The third group consists of six home gardens and encompasses 5 home gardens of $1040 \mathrm{~m}^{2}$ and 16 species. The fourth category is composed of four home gardens with an average area of $2850 \mathrm{~m}^{2}$ to 20 species. It should be noted that there is a garden of $2000 \mathrm{~m}^{2}$ square with 41 species and at the same time there is a home garden with more than $8000 \mathrm{~m} 2$ which has only 12 species. Garden J17 is isolated from other gardens and has only six species with an area of $200 \mathrm{~m}^{2}$. 


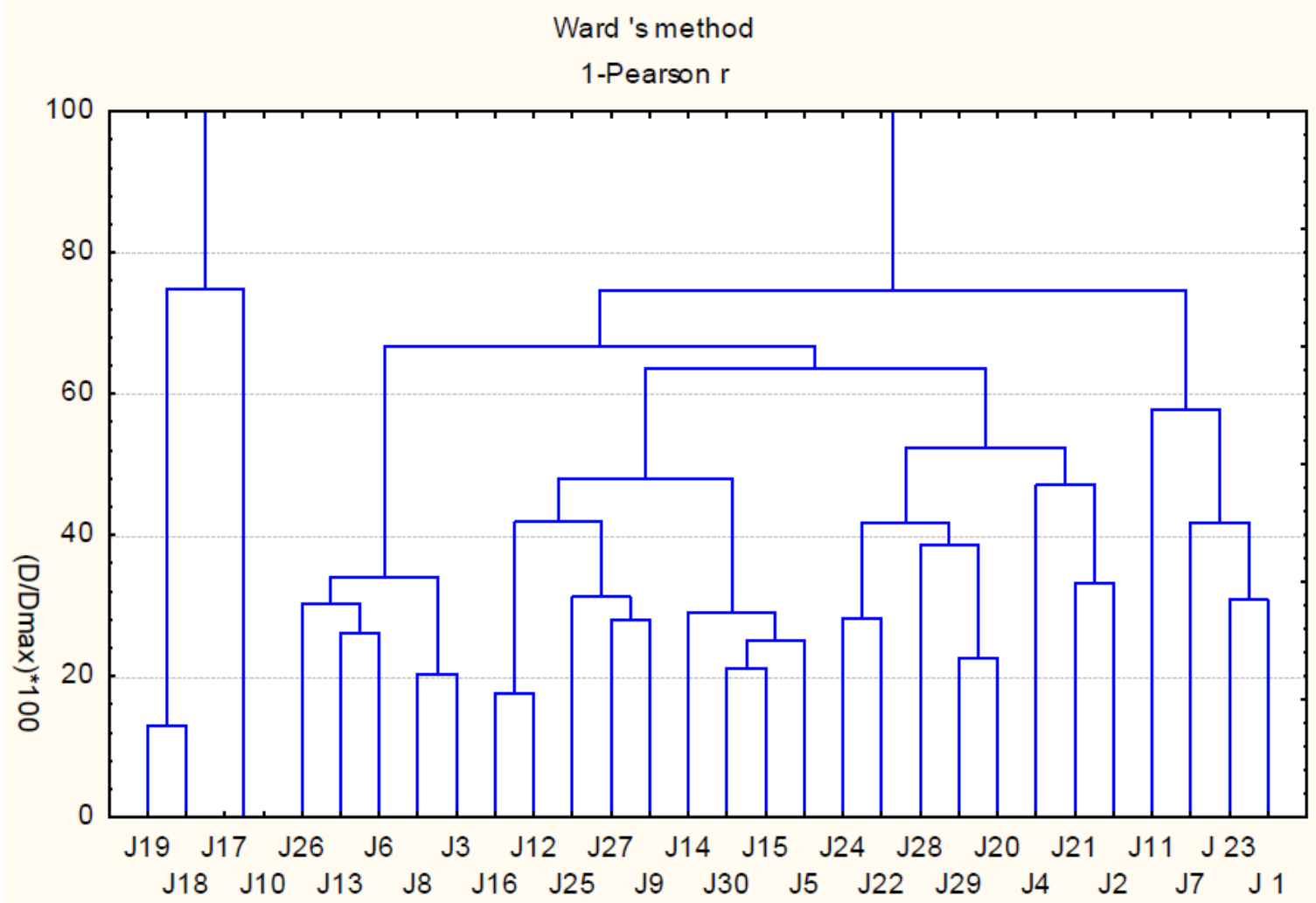

Figure 8. Dendrogram of home gardens in rural zone

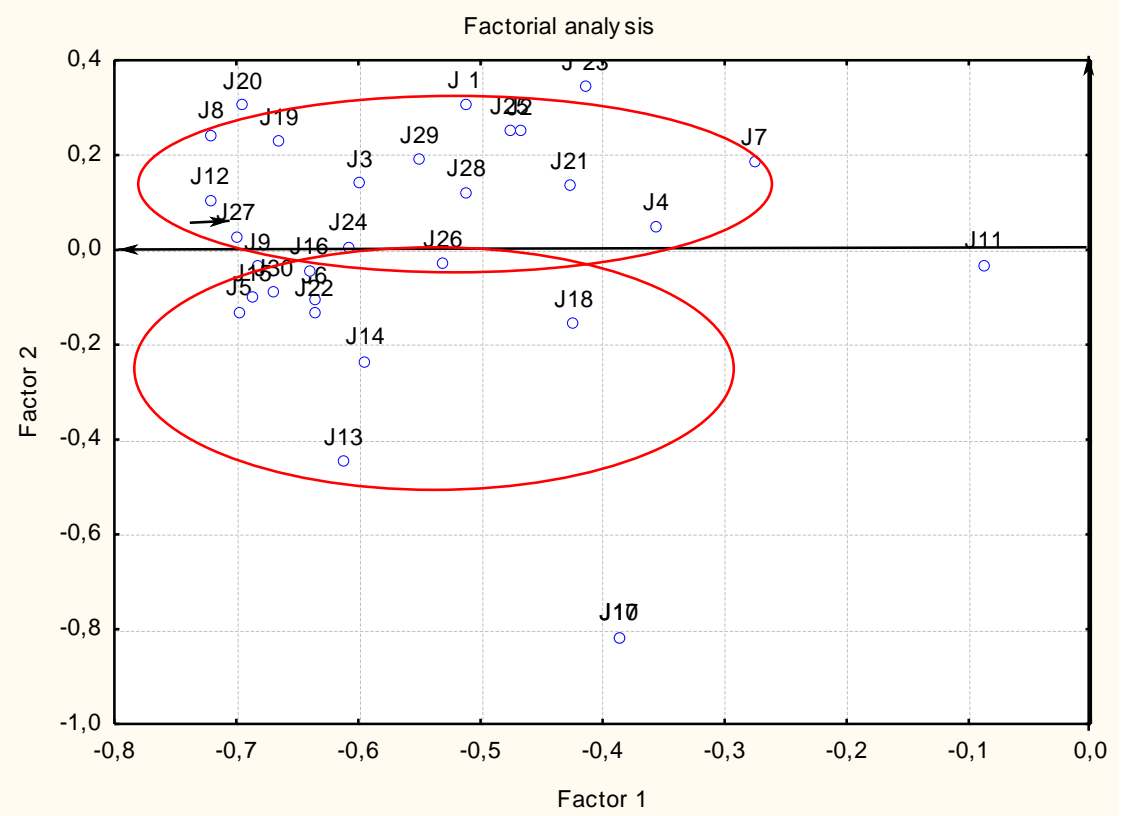

Figure 9. Representation of home gardens on factorial plan in rural zone

As for the factorial analysis of the correspondences, it seems to reveal two main groups as in Figure 9. Thus, if we rely on the Ward algorithm for R2 $=80 \%$, we can discriminate the home gardens into two large groups according to the floristic composition. According to axis 1 , all the home gardens are negatively correlated. This similarity is probably due to the fact that these house gardens are all under the control of man and are not naturally constituted. In relation to axis 2 , there are two categories of gardens. The first group is composed of 
positively correlated gardens and contains about 14 species with an average surface area of $1500 \mathrm{~m}^{2}$. The second group consists of 19 home gardens of which one is composed of 41 species on an area of $2000 \mathrm{~m}^{2}$ and the promoter is a traditional healer. The 18 other gardens have an area ranging from $200 \mathrm{~m}^{2}$ to $2000 \mathrm{~m}^{2}$ and contain an average of 10 species. It is worth noting that the second garden of about $2000 \mathrm{~m}^{2}$ contains only 10 species.

\subsection{Calculation of the Jaccard and Shannon Indices}

From Figure 9, we deduce two classes of home gardens. The Jaccard index between these classes is: $83.7042254 \%$. This indicates that there is a similarity between the two classes between the two categories of house gardens. As for the Shannon indices, they are weak and have $\mathrm{H} 1=1.6719201$ and $\mathrm{H} 2=1.60941666$. On the ecological level, these agrosystems are not very diversified and lead to a strong specialization of the species.

\section{Discussion}

The study of the improvement of the home gardens constitutes an alternative that can serve as a basis for the promotion of family farming. They are able to take into account as a priority, the basic needs of the rural populations. The contribution of the home gardens to the creation of livelihoods has been emphasized by many authors (Fernandes and Nair, 1986, Nair 2006; Shackleton et al., 2008). The home gardens have been described as an important social and economic asset for rural households and the harvested produce significantly improves the nutritional status, health and food security of the families, part of the crops are sold in local and regional markets and this combination is an important means of poverty reduction (Neelamegam et al., 2016). They also create some solidarity between neighboring households, friends and relatives to whom the developer can give these products or sell at fixed prices. Similarly, women influenced significantly the composition of these gardens (Maroyi, 2009). In practice, the estimation of the quantity of production is complex. Indeed, by interviews with users of about ten home gardens, $40 \%$ of staple foods, such as maize, cassava, and plantains, come from these production systems. This proportion can reach $80 \%$ for lipids thanks to the oil palm. The coconut tree for a more complete intake (in carbohydrate, lipid, protein) for the households. The presence of 103 species in the 30 home gardens selected for study in the Abomey-Calavi commune, 55\% of which are food plants, and 29\% of medicinal plants, shows the major role played by this form of production in population satisfaction (Pulido, 2008; Kala, 2010; Aworinder and Erinoso, 2013). It should be almost noted the same number of species has been recorded in the peri urban zone close to this commune with 31 home gardens (Adjahossou et al., 2016). Apart from the large area of the rural home garden, the agrosystems of these two zones have many characteristics in common. The floristic composition of the home garden is identical. In addition, the average percentage of crops grown for nutritional (55. 86\%) and medicinal (24.69\%) needs are almost equally as important. There is a positive correlation between number of species and area of home garden. These resemblances may be due to the proximity of the commune of Abomey-Calavi to the peri-urban zone. With the large home garden in rural zone the owners plant more trees 7, $4 \%$ against $4.6 \%$ in peri urban zone (Adjahossou and al., 2016) Other garden promoters in Abomey-Calavi claim that these systems constitute pantries and cover on average $35 \%$ of the basic needs of the family per month. Products such as Musa sinensis regimes, Elaeis guineensis, Coco nucifera, Citrus sinensis, Ananas comosus, Chrysophyllum albidum, the bread fruit, Tectona grandis, Eucalyptus camadulensis (Figure 10) made from it are sources of income for 22 households that send them to the local markets of Zinvié, Kpanroun, Glodjigbé or even Cotonou. The annual income generated by these gardens is between $5000 \mathrm{~F}$ and $160000 \mathrm{~F}$ CFA in the following table. So, as Aroyi (2009) said in Zimbabwe, the income from the garden is generally very low and between 240 and 800 dollars or 133,000 and 442,400 CFA francs a year. This is relatively insignificant compared to those in the municipality of Abomey-Calavi. Banana is frequently produced in the commune and brings non-negligible income to households. This is confirmed by Lokossou and Achigan, 2000 in their summary report on bananas where its cultivation is concentrated in the southern part of the country in the Departments of the Atlantique, Ouémé, Mono and Zou-Sud. 11 households reported income from home gardens. These incomes are intended to cover expenses such as the schooling of children. In this case 15 to $40 \%$ of the needs are covered by home gardens. It should be noted that, on average, promoters grant 8 to 16 hours of time at most, compared with an average of 48 hours in Zimbabwe (Maroyi, 2009) for the maintenance of the home gardens. It is the reason why they implant these agricultural systems during the rainy season and provides additional irrigation during the dry season (Matahelumual and Verheul, 1987). The frequency of watering depends on the plants (Eijkemans and Ham, 1982). As banana and oil palm does not require much maintenance they play a nutritional and medicinal role and are the main sources of income for households of this commune. The sap of palm trees is used to make the alcoholic beverage called Sodabi. This drink is used in ceremonies or sold branches of palm trees are used to make baskets, brooms, fuel for traditional homes, the closing of the houses. Similarly, barely $27 \%$ of promoters ensure the fertilization of house gardens thanks to animal waste or domestic waste (Mohan, 2004). In fact, some families breed poultry and sheep, goats and pigs for animal protein 
sources. Although these gardens do not bring substantial income to households due to climate change, given the time, sometimes a lack of space for families, they are conservation of biodiversity banks (William, 2004; Nair, 2006) and non-negligible sources of income for some poor families (Neelamegam, 2016). These agrosystems are regularly found in the tropics and subtropics and have an immense importance in the socioeconomic settings of local communities (Mohan, 2004).

Table 1. Annual income of some crops in home gardens

\begin{tabular}{lll}
\hline Products & Number of household & Income per year (F CFA) \\
\hline Ananas comosus & 2 & 20000 à 30000 \\
Musa sinensis & 8 & 20000 à 150000 \\
Coco nucifera & 5 & 40000 à 160000 \\
Cymbopogon citratus & 1 & 5 à 8000 \\
Elaeis guineensis & 6 & 20000 à 80000 \\
Eucalyptus & 2 & 60000 \\
Citrus sinensis & 3 & 10 à 20000 \\
Tectona grandis & 1 & 40000 \\
Chrysophyllum albidum & 2 & 20 à 40000 \\
Bread fruit & 1 & 10 à 15000 \\
Carica papaya & 1 & 5 à 10000 \\
\hline
\end{tabular}

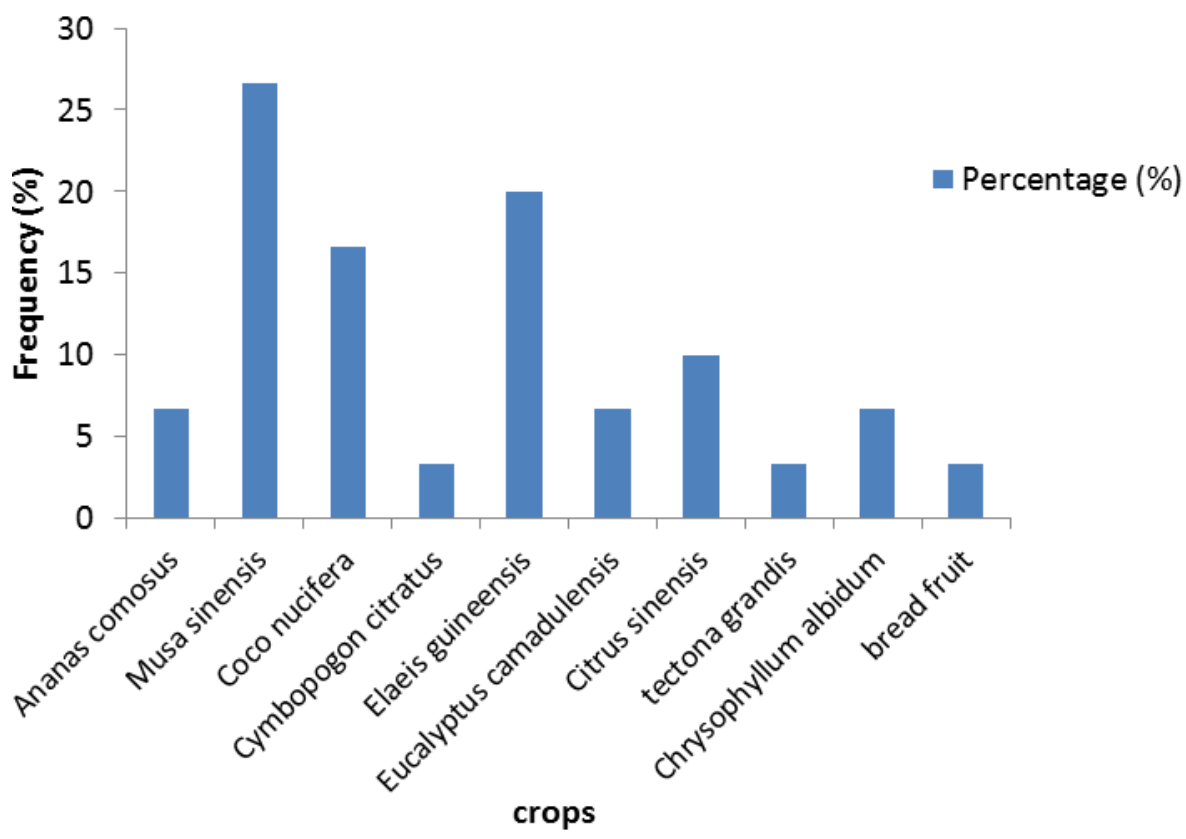

Figure 10. Frequency of commercial products in households

\section{Conclusion}

The continuous exploitation of the home gardens for centuries has played a leading role in the subsistence of man. Better in today's times, this mode of exploitation is one of the best strategies that can sustainably guarantee both food security, appreciable monetary income and the preservation of the environment. One of the important lessons is the efficiency of the system, which with few inputs is a major source of monetary income. The home gardens that have the largest areas suggest the possibility of family farms satisfying the basic needs combined with a community agriculture can optimize returns from cash crops like banana, oil palm, coconut. It is therefore important for States, researchers and ngos to be more interested in these home gardens in order to motivate promoters to improve their productivity for the welfare of all.

\section{Acknowledgment}

The authors sincerely thank the International Foundation for Science (IFS) for financing these research done for this study. They also thank the "Laboratoire d'Ecologie Appliquée" at University of Abomey-Calavi (Republic of 
Benin) for its support.

\section{References}

Abede, T. (2005). Diversity in homegarden agroforestry systems of Southern Ethiopia.Tropical resource manegement papers.Université de Wageningenet Centre de Recherche, Département des Sciences de l'environnement, 143 pages.

Adjahossou, B. S. (2005). Biodiversité végétale, facteur de productivité et de durabilité de l'agriculture : Cas du département de l'Atlantique au Bénin. Thèse de Doctorat Unique.Option: Gestion des Ressources Naturelles, Aménagement du territoire et politique Environnementale. Université d'Abomey-Calavi, $232 \mathrm{p}$

Adjahossou, B. S., Adjahossou, V. N., Djego, J., \& Adjahossou, D. F. (2016). Practice of home gardens (HG) in the Suburban area between Cotonou and Ouidah in Southern Benin. Journal of Biodiversity and Environmental Sciences, 9(5), 29-38.

Allomasso, T. (2001). Conservation des ressources génétiques forestières du Département de l'Atlantique: stratégies de conservation de l'igname sauvage Dioscorea praehensilis (Benth) dans les forêts sacrées et étude de sa domestication. DESS en Aménagement et gestion des ressources naturelles option science et techniques forestières de la Faculté des Sciences Agronomiques, Abomey-Calavi, Bénin, 88 p.

Aworinde, D. O., \& Erinoso, S. M. (2013). Relationship between species composition and homegarden size in Odedalga of ogun state Nigeria.Bayero. Journal of Pure and Applied Sciences, 6(2), 10-18. https://doi.org/10.4314/bajopas.v6i2.3

Castineiras, L., Fundora Mayor, Z., Shagarodsky, T., Moreno, V., Barrios, O., Fernandez, L., \& Cristobal, R. (2001, 17-19 july). Contribution of homegardens to in situ conservation of plant genetic resources in farming systems-Cuban component. In J.W Watson and P. B Eyzaguirre (Eds) Proceedings of the Second International Home Gardens Workshop, Witzenhausen, Federal Republic of Germany,42-55.

Cresta, M., Nouwakpo, F., DE Koning, F., Adandedjan, F. C. C., Agbota, A., Tangni, E., \& Toafode, J. C. (1992). Anthropométrienutritionnelle chez des adultes au sud du Bénin. Riv. Anthropol, 70, 185-198.

Das, T., \& Das, A. K. (2005). Inventorying plant biodiversity in home gardens: A case study in Barak Valley, Assam, North East India. Current science, 89(1), 155-163.

Eijkemans, C., \& van den Ham, A. (1982). Homegarden cultivation in the kabupatenIndramayn (West Java): two case studies. Publikatie Vakgroep Sociale Geographie van de Ontwikkelingslanden, KatholiekeUniversiteit Nijmegen no. 29.

Fernandes, E. C. M., \& Nair, P. K. R. (1986). An evaluation of the structure and function of tropical homegardens. Agricultural Systems, 21, 279-10. https://doi.org/10.1016/0308-521X(86)90104-6

Gaston, K. J., Warren, P. H., Thompson, K., \& Smith, R. M. (2005). Urban domestic gardens (IV): the extent of the resource and its associated features. Biodiversity and Conservation, 14, 3327-49. https://doi.org/10.1007/s10531-004-9513-9

Kala, C. P. (2010). Home Gardens and Management of Key Species in the Pachmarhi Biosphere Reserve of India. J Biodiversity, 1(2), 111-117.

Mapongmetsem, P. M., Nkongmeneck, B. A., Alexandre, D. Y., Salbaï, A., \& Haoua, M. (2002).Jardins de case et sécurité alimentaire dans les savanes souda-guinéennes (Adamaoua, Cameroun). Méga-Tchad, 1, 10.

Maroyi, A. (2009). Traditional homegardens and rural livelihoods in Nhema, Zimbabwe: a sustainable agroforestry system. International Journal of Sustainable Development \& World Ecology, 16(1), 1-8. https://doi.org/10.1080/13504500902745895

Matahelumual, M. M., \& Verheul, M. A. (1987). Vegetables in home gardens on East Java. Scriptie Vakgroep Tropische PLantenteelt, LUW, Wageningen.

Mercer, D. E., \& Miller, R. P. (1998). Socioeconomic research in agroforestry: progress propects, priorities. Agroforestry Systems, 38, 177-193. https://doi.org/10.1023/A:1005964830133

Mohan, S. (2004). An assement of the ecological and socioeconomic benefits provided by home gardens: a case study of Kerala, India. A dissertation presented to the graduate school of the University of Florida, 120.

Nair, P. K. R. (2006). Whither homegardens? Kumar BM, Nair PKR, editors. Tropical homegardens: a time-tested example of sustainable agroforestry, 355-370. Dordrecht: Springer Science.

https://doi.org/10.1007/978-1-4020-4948-4_20 
Neelamegam, R., Sindhu, Prathiba, N., Thangasutha, Muthu, B., Ancy, E. S., Ramani, M., Thangasutha, G., Mohammed, \& Irsath, J. (2017). Household economy and homegarden plants composition, diversity and utilization in rural villages of Kanyakumari District, Tamil Nadu, India, 12-24.

Okigbo, B. N. (1990). Homegardens in Tropical Africa. In K. Landauer, Brazil (Eds.), Tropical Homegardens, 21-40. United Nations University Press, Tokyo, Japan.

Pulido, M. T., Pagaza-Calderón, E. M., Martínez-Ballesté, A., Maldonado-Almanza, B., Saynes, A., \& Pacheco, R. M. (2008). Home gardens as an alternative for sustainability: Challenges and perspectives in Latin America. Research Signpost 37/661(2), Fort P.O., Trivandrum-695 023, Kerala, India Current Topics in Ethnobotany: Editors: Ulysses Paulino de Albuquerque and Marcelo Alves Ramos, 22 pages.

Shackleton, C. M., Paumgarten, F., \& Cocks, M. L. (2008). Household attributes promote diversity of tree holdings in rural areas, South Africa. Agrofor Syst. 72, 221-230.https://doi.org/10.1007/s10457-007-9066-5

Steiner, K. G. (1985). Cultures associées dans les petites exploitations agricoles tropicales en particulier en Afrique de l'Ouest. Deutsche Gesellschaft für Technische Zusammenarbeit (GTZ) Gmbh et Dag-Hammarskjöld-Weg 1+2 ? Postfach 5180, D 6236 Eschborn, 347 pages.

Tynsong, H., \& Tiwari, B. K. (2010). Plant Diversity in the Home gardens and their Significance in the Livelihoods of War KhasiCommunity of Meghalaya, North-east India. J. Biodiversity, 1(1), 1-11.

Williams, D. E. (2004). The conservation and evolution of landraces of peanuts and peppers. In: EYZAGUIRRE, P.B.; LINARES, O.F. (eds.). Home Gardens and Agrobiodiversity. Smithsonian Books, Washington, USA, p. 256-265.

Zaman, S., Siddiquee, S. U., \& Katoh, M. (2010). Structure and Diversity of Home garden Agroforestry in Thakurgaon District, Bangladesh.The Open Forest Science Journal, 3, 38-44. https://doi.org/10.2174/1874398601003010038

\section{Copyrights}

Copyright for this article is retained by the author(s), with first publication rights granted to the journal.

This is an open-access article distributed under the terms and conditions of the Creative Commons Attribution license (http://creativecommons.org/licenses/by/3.0/). 